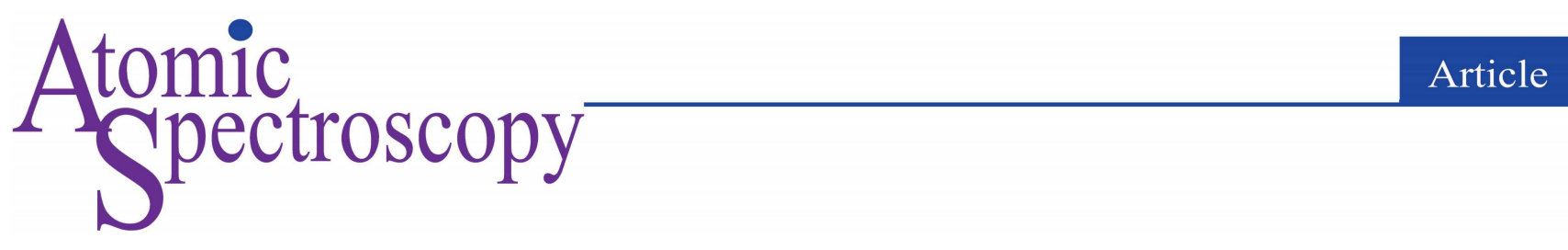

\title{
Multi-elemental Analysis of High-purity Molybdenum by Electrothermal Vaporization-Inductively Coupled Plasma Mass Spectrometry
}

\author{
N.S. Medvedev,* A.V. Volzhenin, and A.I. Saprykin \\ Nikolaev Institute of Inorganic Chemistry, Siberian Branch of Russian Academy of Sciences, Novosibirsk 630090, Russia \\ Received: September 30, 2020; Revised: October 28, 2020; Accepted: October 28, 2020; Available online: November 02, 2020.
}

DOI: $10.46770 / A S .2020 .189$

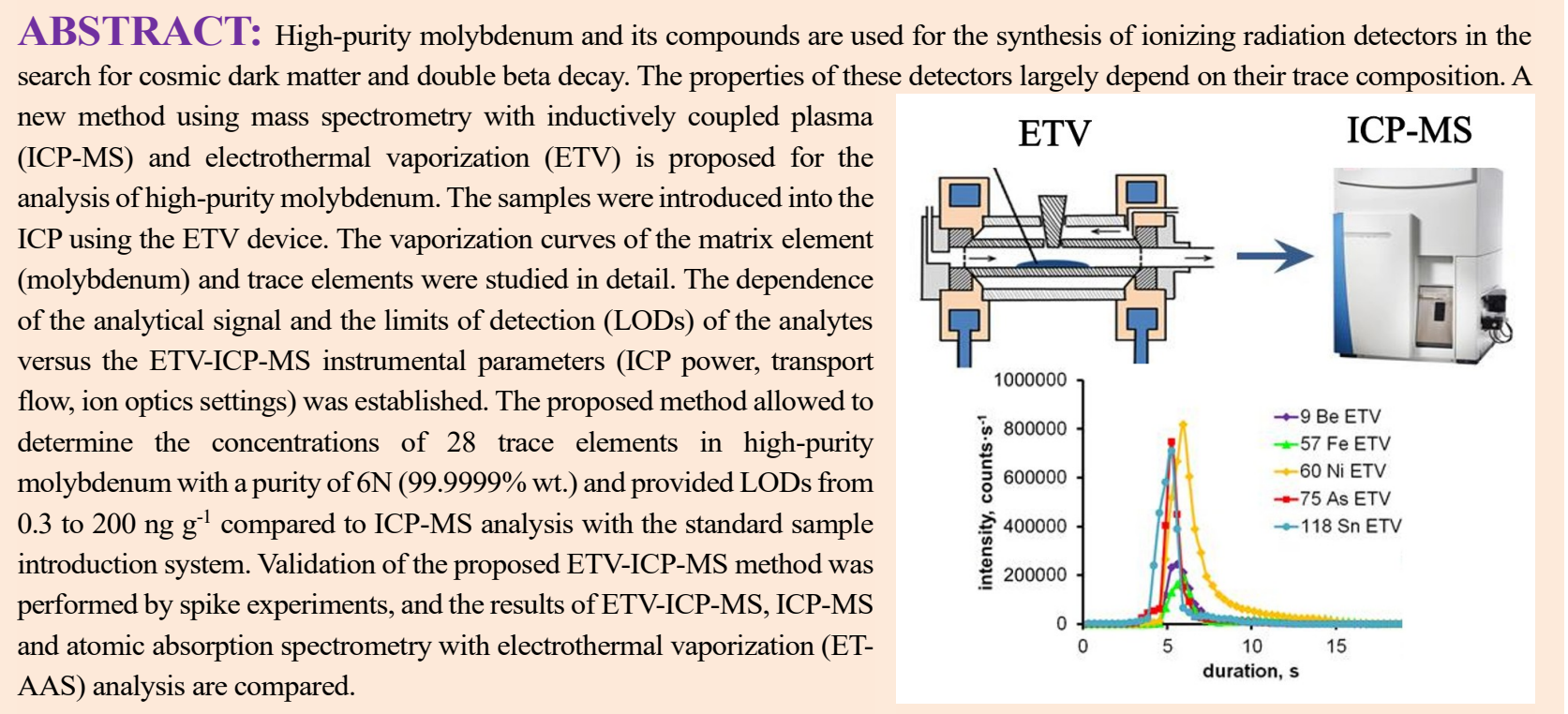

\section{INTRODUCTION}

High-purity molybdenum (Mo) and its compounds are widely used for the synthesis of scintillation materials, such as molybdates of cadmium $(\mathrm{Cd})$, calcium $(\mathrm{Ca})$, lead $(\mathrm{Pb})$, lithium $(\mathrm{Li})$, magnesium $(\mathrm{Mg})$, zinc $(\mathrm{Zn})$, etc. These materials are important for the production of ionizing radiation detectors used in the search for cosmic dark matter and double beta decay. ${ }^{1-4}$ The scintillation properties of these materials largely depend on their trace metal composition. The requirements for the purity of scintillators and their precursors are constantly increasing. ${ }^{5}$ For this reason it is important to develop highly sensitive multielement methods for the trace analysis of high-purity Mo with low LODs of the analytes.

GFAAS is a sensitive trace elemental technique and was reported for analysis of high-purity molybdenum trioxide by slurry sampling, resulting in LODs from 0.03 to $50 \mathrm{ng} \mathrm{g}^{-1}$ for 11 analytes. ${ }^{6}$ Another study obtained LODs for $\mathrm{Ca}, \mathrm{Fe}, \mathrm{K}, \mathrm{Mg}, \mathrm{Mn}$, $\mathrm{Na}$ and $\mathrm{Zn}$ at the 0.03-0.3 $\mathrm{ng} \mathrm{g}^{-1}$ levels. ${ }^{7}$

Inductively coupled plasma-optical emission spectrometry (ICP-OES) with preliminary coprecipitation of the analytes using the lanthanum hydroxide method was proposed for the analysis of high-purity molybdenum ${ }^{8}$ The analytes were separated from the molybdenum matrix by coprecipitation with lanthanum hydroxide So, the high matrix effect of the Mo matrix is avoided, and LODs from 30 to $1900 \mathrm{ng} \mathrm{g}^{-1}$ for $\mathrm{Co}, \mathrm{Cr}, \mathrm{Cu}, \mathrm{Fe}, \mathrm{Mn}, \mathrm{Ni}, \mathrm{Ti}, \mathrm{V}, \mathrm{Zn}$ and $\mathrm{Zr}$ were achieved. ${ }^{8}$ The use of cation exchange was used for separating 42 analytes from the molybdenum matrix. ${ }^{9}$ The cation exchange separation method in combination with GFAAS, ICP- 
OES, ICP-MS and total reflection X-ray fluorescence analysis of Mo has also been studied. Using GFAAS provided LODs from 0.3 to $30 \mathrm{ng} \mathrm{g}^{-1}$ for 16 analytes, using ICP-OES provided LODs from 4 to $770 \mathrm{ng} \mathrm{g}^{-1}$ for 36 analytes, and using ICP-MS provided LODs from 0.1 to $74 \mathrm{ng} \mathrm{g}^{-1}$ for 30 analytes. It is to be noted that the cation exchange column does not allow separating Mo from $\mathrm{As}, \mathrm{Au}, \mathrm{Sb}$, $\mathrm{Se}$, etc., while no information is reported for elements such as $\mathrm{Bi}$, $\mathrm{P}, \mathrm{Sb}$ and $\mathrm{Te}$.

ICP-MS is today the most used multielement and highsensitivity technique for the analysis of high-purity substances with low LODs for the analytes. Pneumatic nebulization of solutions is a standard sample introduction method for ICP-MS and ICP-OES analysis. It is a simple and versatile method that provides high stability of the analytical signal, but has some disadvantages, such as low transport efficiency (usually not exceeding 2-4\%) and requires significant dilution of the sample. Dilution leads to the possibility of uncontrolled contamination of the sample, decreasing the analytical signal and deteriorating the LODs. These facts limit the possibilities of ICP-MS in relation to the analysis of high-purity substances. A significant improvement of the LODs for trace elements can be achieved by the use of ETV for sample introduction into the ICP. ${ }^{10-15}$

ETV is a powerful and highly effective method of sample introduction into the ICP during ICP-MS or OES analysis. ${ }^{16-17}$ During ETV, the sample is evaporated from the resistively heated substrate. As a rule, the standard pyro-coated graphite furnace used in ETV-AAS instrumentation is also used for ETV-ICP-MS and ETV-ICP-OES analysis. Besides, tantalum or tungsten filaments and coils are used. ${ }^{18-21}$ In most of the designs, the aerosol of the evaporated sample is transported into the ICP through a plastic tube by argon gas. The transport efficiency of ETV reaches 20$80 \%{ }^{22-25}$ In addition, ETV requires only a few microliters of sample solution. For this reason, there is no need for a significant dilution of the sample, the analytical signal is increased, the possibility of sample contamination is decreased, and the LODs of the analytes are improved. ETV is also successfully used for the analysis of different samples, such as high-purity substances, environmental samples, biological samples, refractory materials, etc. ${ }^{26-32}$ The possibility of reducing the LODs up to 60 times by the use of ETV for ICP-OES analysis of high-purity molybdenum has already been shown. ${ }^{33}$ For this reason, the development of the ETV-ICP-MS method of analysis high-purity Mo is promising.

In this study, the ETV-ICP-MS method of high-purity Mo analysis has been developed by using ETV for improvement of the LODs. To obtain high analytical signals and low LODs of the analytes, the experimental parameters of ETV-ICP-MS analysis were optimized.

\section{EXPERIMENTAL}

Reagents, materials and labware. Ultrapure water with a resistivity of $18.2 \mathrm{M} \Omega \mathrm{cm}$ was obtained using the Direct-Q 3 water purification system (Millipore, USA). The solutions for quantitative measurements were prepared using multi-element standard solutions (MES) (Skat, Russia) and an ICP-MS-68A solution (High-Purity Standards, USA). The ICP-MS-68A solution contains the following analytes: $\mathrm{Al}, \mathrm{As}, \mathrm{Ba}, \mathrm{Be}, \mathrm{Bi}, \mathrm{B}, \mathrm{Ca}$, $\mathrm{Cd}, \mathrm{Ce}, \mathrm{Cs}, \mathrm{Cr}, \mathrm{Co}, \mathrm{Cu}, \mathrm{Dy}, \mathrm{Er}, \mathrm{Eu}, \mathrm{Fe}, \mathrm{Ga}, \mathrm{Gd}, \mathrm{Ho}, \mathrm{In}, \mathrm{K}, \mathrm{La}, \mathrm{Li}$, Lu, Mg, Mn, Na, Nd, Ni, P, Pb, Pr, Re, Rb, Sc, Se, Sm, Sr, Tb, Tl, Th, Tm, U, V, Y, Zn $\left(10 \mu g \mathrm{~g}^{-1}\right)$. The MES 1 solution contains: Al, $\mathrm{Ca}, \mathrm{Cd}, \mathrm{Cr}, \mathrm{Fe}, \mathrm{K}, \mathrm{Mg}, \mathrm{Mn}, \mathrm{Na}, \mathrm{P}, \mathrm{Zn}\left(50 \mu \mathrm{g} \mathrm{g}^{-1}\right)$, Li $\left(10 \mu \mathrm{g} \mathrm{g}^{-1}\right)$; MES 2 contains: $\mathrm{B}, \mathrm{Bi}, \mathrm{Co}, \mathrm{Cu}, \mathrm{Ga}, \mathrm{In}, \mathrm{Ni}, \mathrm{Si}, \mathrm{Ti}, \mathrm{V}\left(50 \mu \mathrm{g} \mathrm{g}^{-1}\right)$;

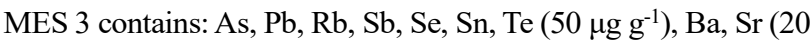
$\left.\mu \mathrm{g} \mathrm{g}^{-1}\right), \mathrm{Ag}, \mathrm{Au}, \mathrm{Be}\left(10 \mu \mathrm{g} \mathrm{g}^{-1}\right), \mathrm{Hg}\left(5 \mu \mathrm{g} \mathrm{g}^{-1}\right)$; MES 4 contains: Hf, Mo, Nb, Re, Ta, W, Zr $\left(50 \mu g^{-1}\right)$; MES REE contains: Ce, Dy, Er, $\mathrm{Eu}, \mathrm{Gd}, \mathrm{Ho}, \mathrm{La}, \mathrm{Lu}, \mathrm{Nd}, \mathrm{Pr}, \mathrm{Sc}, \mathrm{Sm}, \mathrm{Tb}, \mathrm{Tm}, \mathrm{Y}\left(50 \mu \mathrm{g} \mathrm{g}^{-1}\right), \mathrm{Yb}(25$ $\left.\mu \mathrm{g} \mathrm{g}^{-1}\right)$.

Sample preparation. The solution of molybdenum for optimization of the instrumental ETV-ICP-MS and ICP-MS parameters was prepared as follows. High-purity ammonium molybdate $(99.99 \%, 4 \mathrm{~N}, 1.021 \mathrm{~g})$ was dissolved in deionized water., then brought to $50 \mathrm{~mL}$. The working solutions were prepared by further dilution of the initial solution with high-purity water. For testing the accuracy of the ETV-ICP-MS method, the sample of high-purity molybdenum trioxide was used (obtained from the Laboratory of Crystal Growth of the NIIC SB RAS). A 150 -mg portion of high-purity molybdenum trioxide was dissolved in $2 \mathrm{~mL}$ high-purity ammonium hydroxide using a water bath. After this, the solution was diluted with high-purity water to the required concentration. The molybdenum solution for calculation of the LODs was prepared using the high-purity molybdenum sample (6N, 99,9999\%, NIIC SB RAS). $100 \mathrm{mg}$ of the molybdenum sample was dissolved in $0.8 \mathrm{mLof}$ the mixture of high-purity nitric and hydrochloric acid (3:1). Then, the solution was diluted to the required concentration.

ETV-ICP-MS and ICP-MS. The quadrupole-based ICP-MS spectrometer iCAP Qc (Thermo Scientific, USA) was used for this study. The analytical signals were blank-corrected. The main instrumental parameters are listed in Table 1. The scan time for ETV-ICP-MS analysis was 0.35 seconds (20 isotopes were monitored in each run, integration time of $0.01 \mathrm{~s}$, switching takes 0.15 s). All experiments were performed in triplicate $(n=3$, $\mathrm{P}=0.95$ ). The data points represent the average from triplicateindependent experiments. For sample introduction, the ETV device (VMK-Optoelectronica, Russia) was used, as described previously. ${ }^{34}$ The standard $28 \mathrm{~mm}$ length and $5 \mathrm{~mm}$ inner diameter of the pyro-coated graphite furnace tube for GFAAS instrumentation was used for ETV-ICP-MS measurements. For ETV-ICP-MS analysis, $50 \mu \mathrm{L}$ of sample solution was injected into the furnace tube using a micropipette. The injection port was sealed with a graphite probe during the ETV program to prevent 
Table 1. Instrumental Parameters Used for ICP-MS and ETV-ICP-MS Analysis

\begin{tabular}{lcc}
\hline Parameter & ETV-ICP-MS & ICP-MS \\
\hline ICP $($ RF) power & $1300 \mathrm{~W}$ & $1400 \mathrm{~W}$ \\
Plasma argon flow rate & $14 \mathrm{~L} \mathrm{~min}^{-1}$ & $14 \mathrm{~L} \mathrm{~min}^{-1}$ \\
Intermediate argon flow rate & $0.8 \mathrm{~L} \mathrm{~min}^{-1}$ & $0.8 \mathrm{~L} \mathrm{~min}^{-1}$ \\
Carrier gas flow rate & $2.4 \mathrm{~L} \mathrm{~min}^{-1}$ & - \\
Nebulizer argon flow rate & - & $1.1 \mathrm{~L} \mathrm{~min}^{-1}$ \\
Sampling depth & $5 \mathrm{~mm}$ & $5 \mathrm{~mm}$ \\
Voltage of the extraction lens & $-80 \mathrm{~V}$ & $-150 \mathrm{~V}$ \\
Integration time & $0.01 \mathrm{~s}$ & $0.05 \mathrm{~s}$ \\
Number of scans & 1,20 isotopes were monitored in each run & 3 \\
ETV drying step & $90^{\circ} \mathrm{C}, 50 \mathrm{~s}$ & - \\
ETV vaporization of analytes step & $2400^{\circ} \mathrm{C}, 15 \mathrm{~s}$ & - \\
ETV cleaning step & $2400{ }^{\circ} \mathrm{C}, 15 \mathrm{~s}$ & - \\
\hline
\end{tabular}

loss of analytes. The vaporized analytes were swept into the ICP by argon carrier gas through a PTFE tube $(50 \mathrm{~cm}$ long and $4 \mathrm{~mm}$ internal diameter). After each ETV measurement, the clean-out run was carried out. The absence of memory effects was checked by measuring the signal during the clean-out run. After a number of runs $(n=20)$ or when necessary, the graphite furnace was cleaned with a scalpel. The signal vs. time profiles of $\mathrm{Fe}$ and $\mathrm{Mg}$ for ETV and for the clean-out run are presented in the supplementary material, see Fig. S1-S2. The MicroFlow PFA-ST ES 2040 (ESI, USA) nebulizer was used for the ICP-MS measurements with pneumatic nebulization. The determination of $\mathrm{Fe}$ and $\mathrm{P}$ was complicated due to polyatomic interferences. Thus, the helium-filled collision cell was used to reduce them (collision

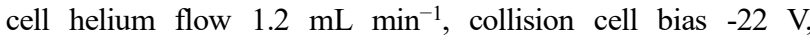
quadrupole bias -20 V). Argon of 99.996 purity was used for ICPMS measurements and helium of 99.9999 purity was used for the collision cell.

GFAAS. The GFAAS measurements were performed using the ICE 3500 atomic absorption spectrometer (Thermo Scientific, USA). For background correction, a Zeeman-effect system was used. The standard graphite tubes were $28 \mathrm{~mm}$ long with a $5 \mathrm{~mm}$ inner diameter. The resonance wavelengths of the analytes were: Ag $328.0 \mathrm{~nm}$, Co $240.7 \mathrm{~nm}$, Mn $279.5 \mathrm{~nm}$, Ni $232.0 \mathrm{~nm}$ (hollow cathode lamps). A $20-\mu \mathrm{L}$ aliquot of the analyzed solution was introduced into the graphite cuvette by micropipette. The concentrations of the analytes were calculated by constructing standard calibration curves ( 5 points and a blank sample). All instrumental parameters for the GFAAS experiments were investigated previously. For constructing a temperature program, the pyrolysis and atomization curves were used.

\section{RESULTS AND DISCUSSION}

Optimization of ETV-ICP-MS instrumental parameters. For ETV-ICP-MS analysis of molybdenum, the ICP-MS instrumental parameters were optimized: ICP (radiofrequency) power, argon gas flow, and extraction lens voltage. The ICP power value varied from 1000 to $1600 \mathrm{~W}$. The maximum analyte signals and minimum LODs of most analytes were obtained when the ICP power was at $1300 \mathrm{~W}$. For lower values of ICP power, the analytical signals dramatically reduced, and the LODs increased. By decreasing the ICP power to $1100 \mathrm{~W}$ leads to decreasing the analyte signals by an average of $40 \%$. Use of ICP power higher than $1300 \mathrm{~W}$ also leads to a decrease in the analyte signals. For example, when $1500 \mathrm{~W}$ is used, the analyte signals decreased on average $30 \%$ compared to the analyte signals at $1300 \mathrm{~W}$. The region for the effective ionization of the analytes can shift to the inductor of the ICP torch when the ICP power is increased. It is to be noted that a change in the sampling depth from the standard 5 $\mathrm{mm}$ to $2.5 \mathrm{~mm}$ and $7.5 \mathrm{~mm}$ does not significantly increase the analyte signals or decrease the LODs.

The transport flow carries the evaporated sample into the ICP during ETV-ICP-MS analysis. It was found that $2.4 \mathrm{~L} \cdot \mathrm{min}^{-1}$ provides the maximum analyte signals and minimal LODs, while flow values lower than $1 \mathrm{~L} \cdot \mathrm{min}^{-1}$ are not sufficient for effective transport of the analytes into the ICP. When the transport flow from 1.0 to $2.0 \mathrm{~L} \cdot \mathrm{min}^{-1}$ is used, the analytical signals do not exceed $40 \%$ of the maximum signals. When the transport flow exceeds $2.4 \mathrm{~L} \cdot \mathrm{min}^{-1}$, the analytical signals decrease. For example, at 3.2 $\mathrm{L} \cdot \mathrm{min}^{-1}$ the analytical signals are on average $50 \%$ of the maximum analyte signal. The voltage of the extraction lens was also optimized for ETV-ICP-MS analysis of molybdenum from -200 to $-20 \mathrm{~V}$. By increasing the extraction lens voltage from -200 to $120 \mathrm{~V}$ on average leads to two times increase of the analytical signals. When the extraction lens voltage from -120 to $-80 \mathrm{~V}$ is used, the analytical signals have similar values. The optimal voltage of the extraction lens is $-80 \mathrm{~V}$ and provides maximal analytical signals and minimal LODs for most of the analytes. A further increase of the extraction lens voltage to $-20 \mathrm{~V}$ leads to a decrease in the analyte signals during ETV-ICP-MS (on average by 4 times) (see Fig. S3-S5).

Optimization of electrothermal vaporization. Generally, there are four steps in the ETV temperature program: drying, pyrolysis, vaporization of the analytes, and cleaning. During the drying step, 
the graphite furnace tube was heated to $\sim 100{ }^{\circ} \mathrm{C}$ for $60 \mathrm{~s}$ to remove the solvent from the sample solution. During the pyrolysis step, a molybdenum solution of $10,000 \mathrm{mg} \mathrm{L}^{-1}$ was evaporated from the graphite furnace tube from room temperature to $2400{ }^{\circ} \mathrm{C}$ (maximum temperature of the ETV device). The current supplied to the graphite furnace was increased step by step from 2 A to 19 $\mathrm{A}$ in $1 \mathrm{~A}$ increments and was registered at every step of heating. Finally, all obtained molybdenum signals were summarized, and the evaporated portion of Mo during each step was calculated. The results are shown in Fig. 1. At the temperature of less than $450{ }^{\circ} \mathrm{C}$ only about $15 \%$ of evaporated molybdenum enters into the ICP. When the graphite furnace tube is heated to $680{ }^{\circ} \mathrm{C}$ and $820^{\circ} \mathrm{C}$, about 45 and $40 \%$ of evaporated molybdenum enters the ICP. With further graphite furnace tube heating, the molybdenum signal decreases. No Mo signal was observed at the temperatures above $960{ }^{\circ} \mathrm{C}$. This dependence can be explained as follows: The molybdenum passes into the gaseous phase in the form of molybdenum oxide, $\mathrm{MoO}_{2} .{ }^{35}$ Thus, if it is necessary to use the pyrolysis step, it must be carried out at $960^{\circ} \mathrm{C}$.

It should be noted that the loss of analytes (evaporation during pyrolysis step) possibly occurs when the pyrolysis step is used for a separate evaporation of the matrix and the analytes. It is necessary to form a full peak of the signal to increase the analytical sensitivity. Vaporization of all of the analytes mentioned in the paragraph "Reagents, Materials and Labware" was studied. The measurements were carried out similar to the study of the molybdenum evaporation, except the solution with a $50 \mu \mathrm{g} \mathrm{L}^{-1}$

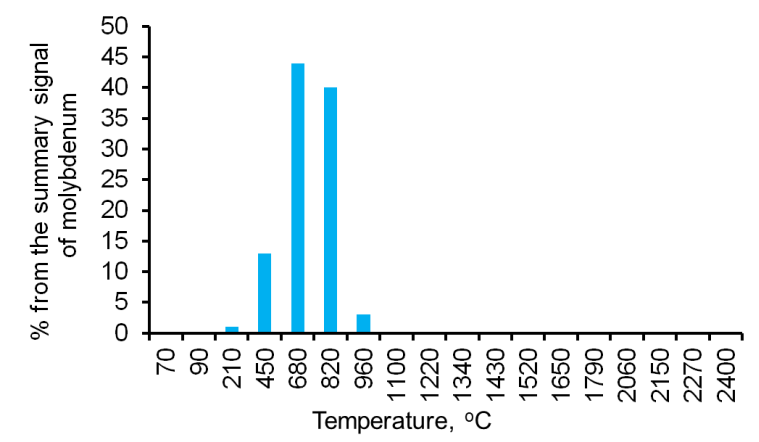

Fig. 1 Molybdenum signal (as a percentage of the summary signal) for heating of the graphite furnace tube to a different temperature.

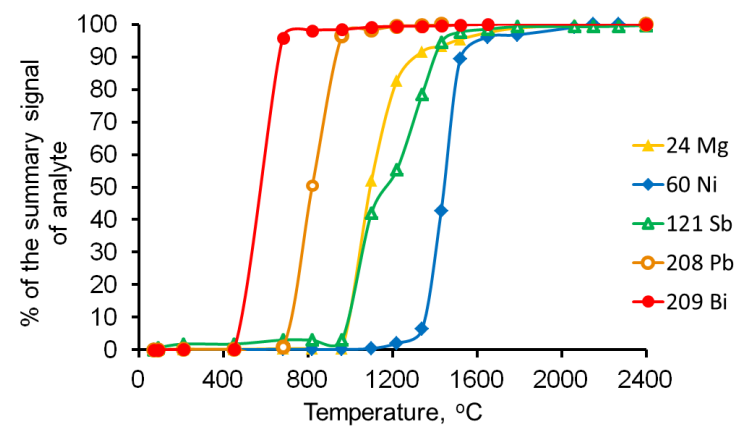

Fig. 2 Vaporization curves of $\mathrm{Bi}, \mathrm{Mg}, \mathrm{Ni}, \mathrm{Pb}$, and $\mathrm{Sb}$. concentration of the analytes and a concentration of $10,000 \mathrm{mg} \mathrm{L}$

${ }^{1}$ Mo was used.

A partial or total vaporization of $\mathrm{Ag}, \mathrm{As}, \mathrm{Bi}, \mathrm{Hg}, \mathrm{P}, \mathrm{Pb}, \mathrm{Se}, \mathrm{Te}$, and $\mathrm{Zn}$ was observed when the pyrolysis step was performed at $960{ }^{\circ} \mathrm{C}$. The vaporization temperature curves of $\mathrm{Bi}, \mathrm{Mg}, \mathrm{Ni}, \mathrm{Pb}$ and $\mathrm{Sb}$ are shown in Fig 2. Thus, it is necessary to evaluate the need for using the pyrolysis stage for ETV-ICP-MS analysis of molybdenum and two different ETV programs were used in this study. The first program included drying $\left(90^{\circ} \mathrm{C}, 50 \mathrm{~s}\right)$, pyrolysis $\left(960{ }^{\circ} \mathrm{C}, 50 \mathrm{~s}\right)$ and vaporization of the analytes $\left(2400{ }^{\circ} \mathrm{C}, 15 \mathrm{~s}\right)$. The second program included drying $\left(90{ }^{\circ} \mathrm{C}, 50 \mathrm{~s}\right)$ and vaporization of the analytes $\left(2400{ }^{\circ} \mathrm{C}, 15 \mathrm{~s}\right)$ without pyrolysis. There was no significant difference for signals of analytes without observed losses during the pyrolysis stage when the first and second ETV programs were used. At the same time, the analysis without use of pyrolysis allows to eliminate the losses (evaporation during pyrolysis step) for $\mathrm{Ag}, \mathrm{As}, \mathrm{Bi}, \mathrm{Hg}, \mathrm{P}, \mathrm{Pb}, \mathrm{Se}$, $\mathrm{Te}$, and Zn. For further ETV-ICP-MS measurements, the temperature program without pyrolysis was used.

The temperature of $2400{ }^{\circ} \mathrm{C}$ was chosen for the analyte vaporization step. The maximum number of analytes vaporized in the ETV device when this temperature value was used included: $\mathrm{Ag}, \mathrm{Al}, \mathrm{As}, \mathrm{Au}, \mathrm{Ba}, \mathrm{Be}, \mathrm{Bi}, \mathrm{Co}, \mathrm{Cr}, \mathrm{Cs}, \mathrm{Fe}, \mathrm{Ga}, \mathrm{Hg}$, In, Li, Mg, Mn, $\mathrm{Ni}, \mathrm{P}, \mathrm{Pb}, \mathrm{Rb}, \mathrm{Re}, \mathrm{Sb}, \mathrm{Se}, \mathrm{Sn}, \mathrm{Sr}$, Te and $\mathrm{Zn}$. Other elements include carbide-forming or refractory elements (the maximum possible temperature of the ETV device heating is insufficient for their vaporization), elements with losses during the drying step, and elements with polyatomic interferences caused by components of the plasma gas: B, Ca, Ce, Dy, Er, Eu, Gd, Hf, Ho, Ir, K, La, Lu, $\mathrm{Na}, \mathrm{Nb}, \mathrm{Nd}, \mathrm{Pr}, \mathrm{Sc}, \mathrm{Si}, \mathrm{Sm}, \mathrm{Ta}, \mathrm{Tb}, \mathrm{Ti}, \mathrm{Th}, \mathrm{Tm}, \mathrm{U}, \mathrm{V}, \mathrm{Y}, \mathrm{Yb}, \mathrm{W}, \mathrm{Zr}$. The concentrations of these elements could not be determined using ETV-ICP-MS analysis of Mo.

The signal vs. time profiles were obtained for all elements mentioned in the paragraph, "Reagents, Materials and Labware." The signal vs. time profiles of Mg for ETV-ICP-MS and for comparison for ICP-MS with pneumatic nebulization are presented in Fig. 3. The comparison with the PN system allowed us to compare the type of signals (transient for ETV and stable in time for $\mathrm{PN}$ ) and their values. The signal vs. time profiles of $\mathrm{Zr}$ for ETV-ICP-MS and for ICP-MS with pneumatic nebulization are shown in Fig. 4. The signal vs. time profiles of $\mathrm{Mg}$ and $\mathrm{Zr}$ show typical dependencies. Since the handles of the graphite furnace are made of copper, there is the risk of a high blank signal for $\mathrm{Cu}$. The clean-out run $\left(2400{ }^{\circ} \mathrm{C}, 15 \mathrm{~s}\right)$ was carried out after each analyte vaporization step.

Calibration during ETV-ICP-MS analysis of molybdenum should be performed by matrix matching. The reason is the significant non-spectral influence of the molybdenum matrix on the analyte signals. Examples of matrix-matched calibration curves and non-matrix-matched curves (solution standard) are presented in Fig. S6 and Fig. S7. This is consistent with literature 


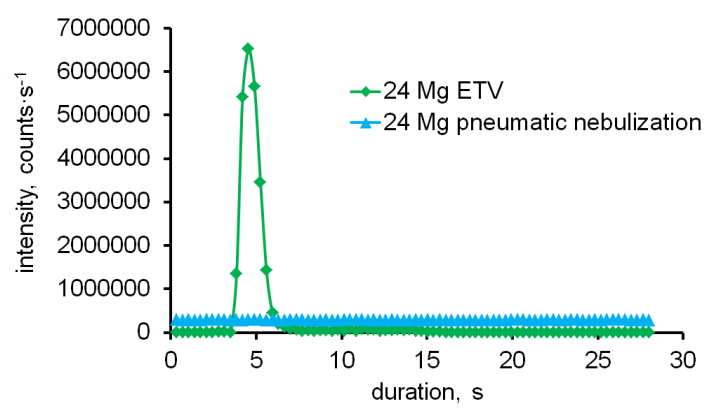

Fig. 3 Signal vs. time profiles of Mg for ETV-ICP-MS and ICP-MS Concentration of $\mathrm{Mg}$ in solutions for ETV-ICP-MS and ICP-MS analysis equals $\left(50 \mu \mathrm{g} \mathrm{L}^{-1}\right)$. For ETV from 0 to $15 \mathrm{~s} ; \mathrm{T}=2400^{\circ} \mathrm{C}$.

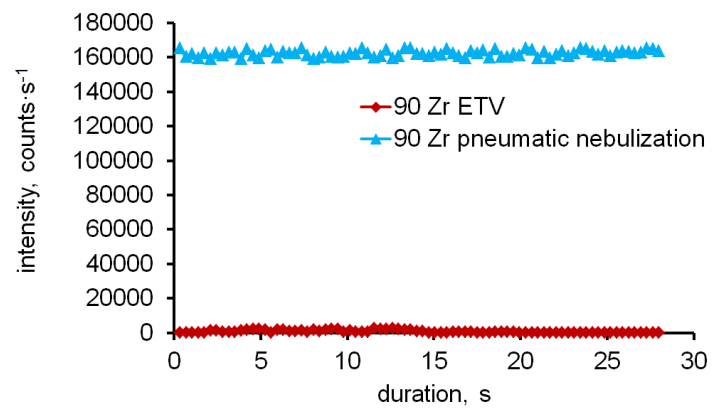

Fig. 4 Signal vs time profiles of $\mathrm{Zr}$ for ETV-ICP-MS and ICP-MS. Concentration of $\mathrm{Zr}$ in solutions for ETV-ICP-MS and ICP-MS analysis equals $\left(50 \mu \mathrm{g} \mathrm{L}^{-1}\right)$. For ETV from 0 to $15 \mathrm{~s} ; \mathrm{T}=2400^{\circ} \mathrm{C}$.

data, which describes that the molybdenum matrix acts as a modifier when the graphite furnace tube is heated. ${ }^{36}$

Evaluation of the LODs of analytes for ETV-ICP-MS analysis of high-purity Mo. The high-purity molybdenum solution was used as a blank sample for evaluation of the LODs of the analytes in ETV-ICP-MS analysis of molybdenum. The concentration of molybdenum in the blank solution was $10,000 \mathrm{mg} \mathrm{L}^{-1}$. The LODs were calculated using $3 s$, where $s$ is the standard deviation of the blank sample signal, $\mathrm{n}=10$. For calibration, the solutions with analyte concentrations of $0.5,2.5,5,25$ and $50 \mu \mathrm{g} \mathrm{L}^{-1}$ and a concentration of Mo at $10,000 \mathrm{mg} \mathrm{L}^{-1}$ were used.

Evaluation of the LODs for ICP-MS analysis of Mo was carried out using the solutions with a Mo concentration of $1000 \mathrm{mg} \mathrm{L}^{-1}$. Dependence of the analyte LODs from the Mo concentration during ICP-MS analysis was studied. The procedure was described previously. ${ }^{37}$ The concentration of molybdenum varied from 50 to $3000 \mathrm{mg} \mathrm{L}^{-1}$. Examples of the dependency of the LODs on the molybdenum concentration are presented in Fig. S8. It was found that the concentration of molybdenum of $1000 \mathrm{mg} \mathrm{L}^{-1}$ provides lowest LODs for most analytes. The solutions with analyte concentrations of $0.5,2.5,5,25$ and $50 \mu \mathrm{g} \mathrm{L}^{-1}$ and a molybdenum concentration of $1000 \mathrm{mg} \mathrm{L}^{-1}$ were used for calibration. The LODs provided by the ETV-ICP-MS and ICP-MS methods are listed in Table 2. The LODs obtained by the proposed ETV-ICP-MS method without Mo matrix and a comparison of the LODs obtained by ICP-MS in the absence of Mo matrix are presented in Table S1.

The ETV-ICP-MS method allowed the simultaneous determination of up to 28 elements in the high-purity molybdenum with LODs ranging from 0.3 to $200 \mathrm{ng} \mathrm{g}^{-1}$. The ETV-ICP-MS LODs of Ag, Al, As, Ba, Be, Bi, Co, Cr, Fe, Ga, Li, Mg, Mn, Ni, $\mathrm{P}, \mathrm{Rb}, \mathrm{Re}, \mathrm{Se}, \mathrm{Sn}, \mathrm{Sr}$, Te and Tl were 3-200 times lower than the ICP-MS LODs. The reasons are the high efficiency of introduction of the samples into the ICP and the low factor of sample dilution. The LODs of $\mathrm{Au}, \mathrm{In}, \mathrm{Pb}, \mathrm{Sb}$ and $\mathrm{Zn}$ for ETV-ICP-MS and ICPMS analysis were found comparable and do not differ more than 3 times. The reason is the fact that despite the higher analytical signals of ETV-ICP-MS, this method has lower stability of the analytical signals and accordingly, a higher standard deviation of the signal.

Table 2. LODs Obtained for ETV-ICP-MS and ICP-MS Analysis of High-purity Molybdenum, ng g ${ }^{-1}$

\begin{tabular}{|c|c|c|c|c|c|c|c|}
\hline Analytical isotope & ETV-ICP-MS* & ICP-MS** & $(2) /(1)$ & Analytical isotope & ETV-ICP-MS* & ICP-MS** & $(2) /(1)$ \\
\hline${ }^{7} \mathbf{L i}$ & 2 & 200 & 100 & ${ }^{85} \mathrm{Rb}$ & 1 & 200 & 200 \\
\hline${ }^{9} \mathbf{B e}$ & 0.3 & 4 & 13 & ${ }^{88} \mathrm{Sr}$ & 3 & 10 & 3 \\
\hline${ }^{24} \mathrm{Mg}$ & 4 & 100 & 25 & ${ }^{107} \mathrm{Ag}$ & 3 & 10 & 3.3 \\
\hline${ }^{27} \mathbf{A l}$ & 7 & 200 & 29 & ${ }^{115} \mathrm{In}$ & 60 & 50 & 0.8 \\
\hline${ }^{31} \mathbf{P}$ & 200 & $2000(800)^{* * *}$ & 10 & ${ }^{118} \mathrm{Sn}$ & 2 & 30 & 15 \\
\hline${ }^{52} \mathrm{Cr}$ & 100 & 300 & 3 & ${ }^{121} \mathrm{Sb}$ & 5 & 6 & 1.2 \\
\hline${ }^{55} \mathrm{Mn}$ & 2 & 70 & 35 & ${ }^{125} \mathrm{Te}$ & 10 & 600 & 60 \\
\hline${ }^{57} \mathrm{Fe}$ & 100 & $2000(300)^{* * *}$ & 20 & ${ }^{133} \mathrm{Cs}$ & 5 & 300 & 60 \\
\hline${ }^{59} \mathrm{Co}$ & 2 & 300 & 150 & ${ }^{137} \mathrm{Ba}$ & 40 & 200 & 5 \\
\hline${ }^{60} \mathrm{Ni}$ & 6 & 100 & 17 & ${ }^{185} \mathrm{Re}$ & 1 & 3 & 3 \\
\hline${ }^{68} \mathrm{Zn}$ & 50 & 100 & 2 & ${ }^{197} \mathrm{Au}$ & 0.8 & 2 & 2.5 \\
\hline${ }^{71} \mathbf{G a}$ & 1 & 5 & 5 & ${ }^{205} \mathrm{Tl}$ & 2 & 9 & 4.5 \\
\hline${ }^{75} \mathrm{As}$ & 10 & 40 & 4 & ${ }^{208} \mathrm{~Pb}$ & 6 & 8 & 1.3 \\
\hline${ }^{77} \mathbf{S e}$ & 20 & 80 & 4 & ${ }^{209} \mathrm{Bi}$ & 4 & 10 & 3 \\
\hline
\end{tabular}

* ETV-ICP-MS - analysis of solution with a molybdenum concentration of $10000 \mathrm{mg} \mathrm{L}^{-1}$.

** ICP-MS - analysis of solution with a molybdenum concentration of $1000 \mathrm{mg} \mathrm{L}^{-1}$.

*** Collision cell was used. 
Table 3. The Results of Addition and Recovery Experiment for ETV-ICP-MS Analysis of High-purity Molybdenum (n=4, $P=0.95)$

\begin{tabular}{|c|c|c|c|c|c|c|c|}
\hline Analyte & Added, ng g $^{-1}$ & Found, ng g $^{-1}$ & Recovery, \% & Analyte & Added, ng g $^{-1}$ & Found, ng g $^{-1}$ & Recovery, \% \\
\hline $\mathbf{L i}$ & 20 & $18 \pm 4$ & 90 & $\mathrm{Rb}$ & 60 & $55 \pm 8$ & 92 \\
\hline Be & 20 & $18 \pm 2$ & 90 & $\mathrm{Sr}$ & 60 & $50 \pm 10$ & 83 \\
\hline Mg & 60 & $55 \pm 8$ & 92 & $\mathrm{Ag}$ & 20 & $25 \pm 5$ & 125 \\
\hline Al & 60 & $75 \pm 20$ & 125 & In & 600 & $700 \pm 100$ & 116 \\
\hline $\mathbf{P}$ & 600 & $650 \pm 100$ & 108 & $\mathrm{Sn}$ & 60 & $60 \pm 10$ & 100 \\
\hline $\mathrm{Cr}$ & 600 & $700 \pm 100$ & 117 & $\mathrm{Sb}$ & 60 & $65 \pm 10$ & 108 \\
\hline Mn & 60 & $55 \pm 9$ & 92 & $\mathrm{Te}$ & 60 & $67 \pm 8$ & 112 \\
\hline $\mathbf{F e}$ & 120 & $130 \pm 20$ & 108 & Cs & 20 & $17 \pm 4$ & 85 \\
\hline $\mathbf{N i}$ & 60 & $60 \pm 10$ & 100 & $\mathrm{Ba}$ & 600 & $540 \pm 90$ & 90 \\
\hline Co & 60 & $70 \pm 10$ & 117 & $\operatorname{Re}$ & 60 & $55 \pm 9$ & 92 \\
\hline $\mathbf{Z n}$ & 60 & $62 \pm 7$ & 103 & $\mathrm{Au}$ & 20 & $17 \pm 5$ & 85 \\
\hline Ga & 60 & $75 \pm 20$ & 125 & $\mathrm{Tl}$ & 20 & $23 \pm 6$ & 115 \\
\hline As & 60 & $70 \pm 20$ & 117 & $\mathrm{~Pb}$ & 60 & $70 \pm 10$ & 117 \\
\hline Se & 60 & $50 \pm 10$ & 83 & $\mathrm{Bi}$ & 60 & $50 \pm 10$ & 83 \\
\hline
\end{tabular}

Table 4. The Results of Analysis of High-purity Molybdenum Sample ( $(n=4, P=0.95)$

\begin{tabular}{|c|c|c|c|c|c|c|c|}
\hline Analyte & ETV-ICP-MS, ng g ${ }^{-1}$ & ICP-MS, ng g $^{-1}$ & ETAAS, ng g $^{-1}$ & Analyte & ETV-ICP-MS, ng g-1 & ICP-MS, ng g $^{-1}$ & ETAAS, ng g $^{-1}$ \\
\hline $\mathbf{L i}$ & $<2$ & $<200$ & - & $\mathrm{Rb}$ & $<1$ & $<200$ & - \\
\hline $\mathbf{B e}$ & $<0.3$ & $<4$ & - & $\mathrm{Sr}$ & $<3$ & $<10$ & - \\
\hline Mg & $<4$ & $<100$ & - & $\mathrm{Ag}$ & $<3$ & $<10$ & $<0.5$ \\
\hline Al & $800 \pm 200$ & $600 \pm 100$ & - & In & $<60$ & $<50$ & - \\
\hline $\mathbf{P}$ & $<200$ & $<800$ & - & Sn & $<2$ & $<30$ & - \\
\hline $\mathbf{C r}$ & $2000 \pm 300$ & $1800 \pm 200$ & - & $\mathrm{Sb}$ & $<5$ & $<6$ & - \\
\hline $\mathbf{F e}$ & $1000 \pm 200$ & $800 \pm 100$ & - & $\mathrm{Te}$ & $<10$ & $<600$ & - \\
\hline Mn & $600 \pm 100$ & $650 \pm 90$ & $500 \pm 100$ & Cs & $<5$ & $<300$ & - \\
\hline $\mathbf{N i}$ & $1000 \pm 200$ & $900 \pm 100$ & $900 \pm 100$ & $\mathrm{Ba}$ & $<40$ & $<200$ & - \\
\hline Co & $500 \pm 100$ & $450 \pm 90$ & $400 \pm 60$ & $\operatorname{Re}$ & $<1$ & $<3$ & - \\
\hline $\mathbf{Z n}$ & $<50$ & $<100$ & - & $\mathrm{Au}$ & $<0.8$ & $<2$ & - \\
\hline Ga & $<1$ & $<5$ & - & $\mathrm{Tl}$ & $<2$ & $<9$ & - \\
\hline As & $<10$ & $<40$ & - & $\mathrm{Pb}$ & $<6$ & $<8$ & - \\
\hline Se & $<20$ & $<80$ & - & $\mathrm{Bi}$ & $<4$ & $<10$ & - \\
\hline
\end{tabular}

The proposed method of ETV-ICP-MS analysis for high-purity molybdenum permits controlling the concentration of 28 trace elements in molybdenum with a purity of $6 \mathrm{~N}(99.9999 \%$ wt.). In comparison, ICP-MS allows to characterize molybdenum with a purity of only $99.999 \%(5 \mathrm{~N})$ for these analytes. The limitation of the proposed ETV-ICP-MS method is the impossibility of determining the concentration of refractory and carbide-forming elements, for example $\mathrm{Ir}, \mathrm{Nb}, \mathrm{W}$, etc.

For a comparison of the proposed ETV-ICP-MS method with existing methods of high-purity molybdenum analysis, we would like to provide the following conclusions. The ICP-MS method of analysis of high-purity molybdenum with a preliminary matrix and analyte separation by cation exchange column has similar or lower LODs compared to the proposed ETV-ICP-MS method. The LODs of 27 analytes ranged from 0.1 to $74 \mathrm{ng} \mathrm{g}^{-1} .^{12}$ The dilution factor for the ICP-MS method with preliminary ion exchange was 15 , whereas in the present study the dilution factor for ETV-ICP-MS was 100. At the same time, As, Au, Sb and Se cannot be separated from the molybdenum matrix using the cation exchange column; however, the proposed ETV-ICP-MS method allows the determination of these elements. Use of the preliminary separation of the sample matrix from the analytes increases the risk of contamination of the analyzed sample and is a time-consuming procedure. Using the concentration of analytes by distilling off the matrix of the sample for ICP-OES analysis of molybdenum oxide permits to achieve LODs from 0.5 to $50 \mathrm{ng} \mathrm{g}^{-1}$ for 14 analytes. ${ }^{38}$ These values are comparable to or slightly higher than the LODs provided by ETV-ICP-MS analysis. Note that for a number of elements, losses are possible when the sample matrix is distilling off.

Validation of ETV-ICP-MS analysis of high-purity molybdenum. For validation of the ETV-ICP-MS method for high-purity molybdenum analysis, the "spike" experiment was used. The analytes were added to the samples from the MES solutions before dissolution of the ammonium molybdate was performed. Then the spiking solutions were prepared the same as the initial solution of molybdenum. The spiked concentrations of the target elements were picked close to the limits of detection, but the contents in the original samples may vary. For the ETV-ICPMS "spike" experiment, the calibration was performed using blank 
solutions and five calibration solutions with analyte concentrations from 0.5 to $50 \mu \mathrm{g} \mathrm{L}^{-1}(\mathrm{n}=3, \mathrm{P}=0.95)$. Also, a clean-out run and blank solution measurements were carried out. The signals of the spiked solutions were measured $(\mathrm{n}=3, \mathrm{P}=0.95)$, and the results are presented in Table 3. As can be seen, good recovery was obtained for the studied analytes.

Also, a comparison of the results of ETV-ICP-MS, ICP-MS and GFAAS analysis of the high-purity molybdenum sample was performed (Table 4). For the ICP-OES technique, significant spectral interferences of molybdenum on the analyte lines were observed. The ICP-OES technique has been described previously. 33,39 The LODs of most analytes provided by ICP-OES are significantly higher than by ICP-MS. So, the analyte contents at the required concentration level cannot be defined. The good agreement between results of the ETV-ICP-MS, ICP-MS and GFAAS analyses of the high-purity molybdenum sample confirmed the accuracy of proposed ETV-ICP-MS method. The difference is insignificant since the confidence intervals overlap.

\section{CONCLUSIONS}

In this study, the proposed ETV-ICP-MS method allowed us to characterize the molybdenum with purity of $99.9999 \%(6 \mathrm{~N})$. The LODs of Ag, Al, As, Ba, Be, Bi, Co, Cs, Cr, Fe, Ga, Li, Mg, Mn, $\mathrm{Ni}, \mathrm{P}, \mathrm{Rb}, \mathrm{Re}, \mathrm{Se}, \mathrm{Sn}, \mathrm{Sr}, \mathrm{Te}$ and $\mathrm{Tl}$ provided by ETV-ICP-MS method are 3-200 times lower comparing with the LODs provided by ICP-MS analysis with standard pneumatic nebulization. The achieved values of ETV-ICP-MS LODs are up to $0.3 \mathrm{ng} \mathrm{g}^{-1}$. The detailed study of molybdenum and analytes vaporization curves was performed. It was shown that using the chosen ETV heating program provides efficient evaporation of the 28 analytes and their introduction into the ICP. The proposed ETV-ICP-MS method is quite rapid (an analysis cycle requires about $2 \mathrm{~min}$ ), simple and provides good accuracy and precision. The proposed ETV-ICPMS method is highly sensitive, multielemental and can be used for trace analysis of molybdenum compounds with appropriate sample preparation. It can be useful for control of trace composition of precursors for the synthesis of molybdates with scintillation properties.

\section{ASSOCIATED CONTENT}

Please contact the corresponding author for the Supporting Information (Table S1 and Fig. S1-S8).

\section{AUTHOR INFORMATION}

\section{Corresponding Author}

* N. S. Medvedev

Email address: medvedev@niic.nsc.ru

\section{Notes}

The authors declare no competing financial interest.

\section{ACKNOWLEDGMENTS}

This study was financially supported by the grant of Russian Science Foundation (Project No. 18-73-00039).

\section{REFERENCES}

1. L. L. Nagornaya, F. A. Danevich, A. M. Dubovik, B. V. Grinyov, S. Henry, V. Kapustyanyk, H. Kraus, D. V. Poda, V. M. Kudovbenko, V. B. Mikhailik, M. Panasyuk, O. G. Polischuk, V. Rudyk, V. Tsybulskyi, I. A. Tupitsyna, and Y. Y. Vostretsov, IEEE Trans. Nucl. Sci., 2009, 56, 2513-2518. https://doi.org/10.1109/TNS.2009.2022268

2. A. P. Shcherban, Probl. At. Sci. Technol., 2011, 6, 3-10.

3. D. M. Chernyak, F. A. Danevich, V. Y. Degoda, I. M. Dmitruk, F. Ferri, E. N. Galashov, A. Giuliani, I. M. Ivanov, V. V. Kobychev, M. Mancuso, S. Marnieros, V. M. Mokina, C. Nones, E. Olivieri, G. Pessina, C. Rusconi, V. N. Shlegel, O. P. Stanovyi, M. Tenconi, V. I. Tretyak, and I. A. Tupitsyna, Nucl. Instrum. Meth. A, 2013, 729, 856-863. https://doi.org/10.1016/j.nima.2013.07.088

4. F. A. Danevich, Int. J. Mod. Phys. A., 2017, 30, 1743008-1 1743008-16. https://doi.org/10.1142/S0217751X17430084

5. P. Lecoq, A. Gektin, and M. Korzhik. Influence of the Crystal Structure Defects on Scintillation Properties. Berlin, Springer, Heidelberg, 2006. https://doi.org/10.1007/3-540-27768-4_4

6. B. Docecal and V. Krivan, J. Anal. At. Spectrom., 1993, 8, 637-641. https://doi.org/10.1039/JA9930800637

7. B. Docecal, Spectrochim. Acta B, 1998, 53, 427-435. https://doi.org/10.1016/S0584-8547(97)00132-8

8. O. Kujirai, K. Yamada, M. Kohri, and N. Okochi, Fresen. J. Anal. Chem., 1991, 339, 133-136. https://doi.org/10.1007/BF00324398

9. V. Krivan and K. Theimer, Spectrochim. Acta B, 1997, 52, 2061-2076. https://doi.org/10.1016/S0584-8547(97)00105-5

10. D. E. Nixon, V. A. Fassel, and R. N. Kniseley, Anal. Chem., 1974, 46(2), 210-213. https://doi.org/10.1021/ac60338a018

11. A. M. Gunn, D. L. Millard, and G. F. Kirkbright, Analyst, 1978, 103, 1066-1073. https://doi.org/10.1039/an9780301066

12. J. S. Becker and H. J. Dietze, Int. J. Mass spectrom., 2003, 228, 127-150. https://doi.org/10.1016/S1387-3806(03)00270-7

13. S. Chen, S. Zhu, and D. Lu, At. Spectrosc., 2015, 36, 196-201. https://doi.org/10.46770/AS.2015.05.002

14. S. Chen, J. Li, D. Lu, and S. Zhu, At. Spectrosc., 2016, 37, 13-18. doi.org/10.46770/AS.2016.01.003

15. Y. Cui, L. Jin, H. Li, S. Hu, and Y. Lian, At. Spectrosc., 2020, 41, 87-92. doi.org/10.46770/AS.2020.02.006

16. M. Resano, F. Vanhaecke, and M. T. C. de Loos-Vollebregt, J. Anal. At. Spectrom., 2008, 23, 1450-1475. https://doi.org/10.1039/b807756h

17. B. Hu, S. Li, G. Xiang, M. He, and Z. Jiang, Appl. Spectrosc. Rev, 2007, 42, 203-234. https://doi.org/10.1080/05704920601184317

18. D. E. Nixon, V. A. Fassel, and R. N. Kniseley, Anal. Chem., 1974, 46, 210-213. https://doi.org/10.1021/ac60338a018.

19. P. Barth, S. Hauptkorn, and V. Krivan, J. Anal. At. Spectrom., 1997, 
12, 1359-1365. https://doi.org/10.1039/ja9920700521.

20. H. R. Badiei, B. Lai, and V. Karanassios, Spectrochim. Acta B, 2012, 77, 19-30. https://doi.org/10.1016/j.sab.2012.07.025.

21. S. N. Hanna, C. P. Calloway, J. D. Sanders, R. A. Neslon, J. Cox, and B. T. Jones, Microchem. J., 2011, 99, 165-169, https://doi.org/10.1016/j.microc.2011.04.009.

22. H. Baumann, Fresen. J. Anal. Chem., 1992, 342, 907-916. https://doi.org/10.1007/BF00322826

23. S. M. Schmertmann, S. E. Longt, and R. F. Browner, J. Anal. At. Spectrom., 1987, 2, 687-693. https://doi.org/10.1039/JA9870200687

24. U. Schaffer and V. Krivan, Anal. Chem., 1998, 70, 482-490. https://doi.org/10.1021/ac9708349

25. M. E. Rybak and E. D. Salin, J. Anal. At. Spectrom., 2000, 15, 883-887. https://doi.org/10.1039/B001790f

26. K. D. Ohls, Microchim. Acta, 1989, 99, 337-346. https://doi.org/10.1007/BF01244689.

27. V. Karanassios, J. M. Ren, and E. D. Salin, J. Anal. At. Spectrom., 1991, 6, 527-533, https://doi.org/10.1039/ja9910600527.

28. L. Moens, T. Veppert, S. Boonen, F. Vanhaecke, and R. Dams, Spectrochim. Acta B, 1995, 50, 463-475. https://doi.org/10.1016/0584-8547(94)00153-M

29. Y. Okamoto, Fresen. J. Anal. Chem., 2000, 367, 295-299. https://doi.org/10.1007/s002160000340.

30. K. C. Friese and V. Krivan, Fresen. J.Anal. Chem., 1999, 364,
72-78. https://doi.org/10.1007/s002160051303.

31. J. Hassler, P. Barth, S. Richter, and R. Matschat, J. Anal. At. Spectrom., 2011, 26, 2404-2418. https://doi.org/10.1039/C1JA10149H

32. F. Kaveh, C. J. Oates, and D. Beauchemin, Geochem.: Explor, Environ., Anal., 2014, 14, 305-313. https://doi.org/10.1144/geochem2013-230

33. N. S. Medvedev, A. V. Malitskii, A. R. Tsygankova, and A. I. Saprykin, J. Anal. Chem., 2018, 73, 533-538. https://doi.org/10.1134/S1061934818060072

34. N. S. Medvedev, A. V. Shaverina, A. R. Tsygankova, and A. I. Saprykin, Talanta, 2016, 155, 358-362. https://doi.org/10.1016/j.talanta.2016.02.052

35. C. L. Chakrabarti, S. Wu, F. Marcantonio, and K. L. Headrick, Fresenius Z. Anal. Chem., 1986, 323, 730-736. https://doi.org/10.1007/BF00467067

36. D. L. Tsalev, V. I. Slaveykova, and P. B. Mandjukov, Spectrochim. Acta Rev., 1990, 13, 225-274. https://archive-ouverte.unige.ch/unige: 17980

37. N. S. Medvedev, A. V. Shaverina, A. R. Tsygankova, and A. I. Saprykin, Spectrochim. Acta B, 2018, 142, 23-28. https://doi.org/10.1016/j.sab.2018.01.017.

38. A. R. Tsygankova, I. R. Shelpakova, V. A. Shestakov, and A. I. Saprykin, Zav. Lab. Diagn. Mat., 2010, 76, 3-6.

39. A. R. Tsygankova, G. V. Makashova, I. R. Shelpakova, and A. I. Saprykin, Analitika i Kontrol., 2011, 15, 182 